by Gerd Geyer*

\title{
A comprehensive Cambrian correlation chart
}

Lehrstuhl für Geodynamik und Geomaterialwissenschaft, Institut für Geographie und Geologie, Bayerische Julius-Maximilians-Universität, Würzburg, Germany; *Corresponding author,E-mail: gerd.geyer@uni-wuerzburg.de

(Received: June 7, 2019; Revised accepted: November 8, 2019)

https://doi.org/10.18814/epiiugs/2019/019026

The International Subcommission on Cambrian Stratigraphy has introduced a number of internal subdivisions (i.e., series and stages), but most of the explanatory publications lack reliable data on the correlation between all Cambrian key continents. A comprehensive correlation chart is presented here to review and document correlatable biostratigraphic horizons within the system and correlation of biostratigraphic zones and regional series and stages, accompanied by explanatory remarks. The chart also presents important available non-biological correlation data, such as carbon isotope signatures and radiometric ages.

\section{Introduction}

In 1999, the officers of International Subcommission on Cambrian Stratigraphy (ISCS) launched the Cambrian Subdivision Project with the goal to introduce formal internal international stages and series for the Cambrian period (Geyer and Shergold, 2000; Shergold and Geyer, 2001; Babcock et al., 2005). Until that time, the Cambrian was without any formal subdivision, but instead had "parochial subdivisions in many areas which primarily satisfied regional requirements. This project of the ISCS experienced growing international interest since the start of Field Workshops starting in Morocco 1995. The recognition of formal international stages or series for the Cambrian since then has developed into the major task of Cambrian stratigraphers.

Geyer and Shergold (2000) reviewed and examined possibilities for Cambrian subdivisions on the basis of faunal horizons with potential for international correlation. The ISCS introduced a first global internal GSSP in 2003 for the base of the Furongian Series and Paibian Stage (Peng et al., 2004). It was followed by the GSSP for the base of the Drumian Stage (Babcock et al., 2007), the GSSP for the base of the Guzhangian Stage (Peng et al., 2006, 2009), the GSSP for the base of the Jiangshanian Stage (Peng et al., 2012), and the GSSP on the base of the Miaolingian Series and Wuliuan Stage (Zhao et al., 2018, 2019). The formal naming of the Terreneuvian Series and Fortunian Stage, defined by the GSSP for the Cambrian lower boundary, took place in 2007 (Landing et al., 2007).

The choice of GSSPs reflects the difficulties about the selection of globally recognizable biostratigraphic horizons, which in turn have to rely on the simplicity of interregional, intercontinental and global cor- relation. The long period between the introduction of the Jiangshanian in 2012 and the Miaolingian/Wuliuan in 2018 indicates the growing difficulties to arrive at a readily acceptable horizon. The reasons for these difficulties can be seen in real difficulties based on the presence/absence of biostratigraphically useful fossils; gaps/hiatuses in the successions; and simply a lack of data. In many cases, however, the difficulties result from differing taxonomic concepts; incomplete knowledge on the data of regions other than the specialties of the scientist's particular working area; or even biased, nationalistic views that led to erroneous correlations.

\section{Preliminary remarks}

In order to provide a sound base for future discussions on the stratigraphy of the Cambrian, a comprehensive correlation table is presented here for all key areas with Cambrian successions. The remarks on particular stratigraphic intervals and peculiarities on single Cambrian continents are kept here to a minimum if the key issues are already discussed in easily accessible publications.

The stratigraphical information in the columns include regional series (as far as available) and stages as well as the most reliable and usually latest established biostratigraphic subdivisions. Also included are radiometric age determinations and carbon isotope signatures that are regarded as significant. It should be noted that some of the radiometric ages refer to maximum ages (e.g., for the base of the Tommotian of the Siberian Platform) so that these apparently do not correlate precisely with ages from other regions in at the same levels.

The carbon isotope signatures are divided into significant positive (ochre stars) and negative (green stars) peaks. It is obvious that they do not plot to perfectly coeval events, which can be explained by different circumstances. Following the recognition of the SPICE (Steptoean Positive Carbon Isotope Excursion) event by Saltzman et al. $(1998,2000)$ and the HERB (HEllnmaria-Red Tops Boundary) event by Ripperdan (2002), a discrete scheme of carbon isotope signatures throughout has been suggested by Zhu et al. (2006), including the BACE (BAsal Cambrian carbon isotope Excursion), ZHUCE (ZHUjiaqing Carbon isotope Excursion), SHICE (SHIyantou Carbon isotope Excursion), CARE (Cambrian Arthropod Radiation isotope Excursion), MICE (MIngxinsi Carbon Isotope Excursion), AECE (Archaeocyathid Extinction Carbon isotope Excursion), ROECE (Redlichiid-Olenellid Extinction Carbon isotope Excursion), DICE 
(DrumIan Carbon isotope Excursion), and TOCE (Top of Cambrian Excursion). However, it appears to be the case that some of these peaks are not globally recognizable. Some, such as the HERB and TOCE signatures were subject to confusion. Both are now generally regarded as the representing same fluctuation in ocean chemistry (N3 peak of Li et al., 2017, for South China). In addition, additional excursions can be recognized. Here, it is suggested that the positive peak determinable in the Repinaella Zone of the Siberian Platform (local name carbon isotope excursion IV in Brasier et al., 1994, fig. 4), albeit rarely recognized to date, is valuable for correlation and is named EAREZE (Early Atdabanian/REpinaella Zone Excursion) (see Landing et al., 2013b). Additional complications in the carbon isotope curves result from obvious diagenetic overprint. Finally, a number of the signatures have been referred by the authors to lithological units without a direct link to the relevant biostratigraphical/chronostratigraphical level. As an example, data in Maloof et al. $(2005,2010)$ were investigated in sections without precise constrain between lithostratigraphy and biostratigraphy, and their transfer to the standard stratigraphic scheme suffer from inaccuracies.

\section{Fortunian}

The Fortunian (Landing et al., 2007) is commonly regarded as a stage generally with a fossil content characterized largely by trace fossils. A common misunderstanding exists in the assumption that the complex trace Treptichnus (or Trichophycus) pedum is the index fossil for the base of the Cambrian system, Terreneuvian Series and Fortunian Stage, which is not the case. In fact, the lowest occurrence of Treptichnus pedum in the T. pedum Assemblage Zone of Fortune Head section in southeastern Newfoundland designates the GSSP of the lower boundary of the Cambrian system, and boundary designations in all other regions must be referred to this level. Facts about the definition and historical development of this boundary and the oldest Cambrian strata are summarized in Geyer and Landing (2016).

The choice of ichnofossils as indicators for the base of the Cambrian resulted from the insight that "Small Shelly Fossils (favoured as stratigraphical indicators in pre-trilobitic Cambrian strata until the late 1980s) were unsuitable for detailed biostratigraphic zonations and precise intercontinental correlation. They were assumed to be predated by ichnofossils as the relics of non-skeletonised earliest Cambrian bilaterian assemblages. Meanwhile it was shown that some of the earliest known skeletal elements at the dawn of bilaterians with mineralised sclerites occur in the established terminal Ediacaran-Fortunian boundary interval. Such taxa include Protohertzina anabarica, Anabarites trisulcatus, and Cambrotubulus decurvatus known from the Siberian Platform as well as the Yangtze/South China Platform (Nagovitsin et al., 2015; Wood et al., 2017; Zhu et al., 2017). In South China, the Protohertzina anabarica-Anabarites trisulcatus Assemblage Zone ranges just above the BACE carbon isotope signature (Steiner et al., 2007; Cai et al., 2019). For the Siberian Platform, Anabarites trisulcatus was shown to predate Protohertzina anabarica (e.g., Zhuravlev et al., 2015) and their occurrences are now regarded as indicating subsequent zones, with the $A$. trisulcatus Chron as the terminal Ediacaran interval and the $P$. anabarica Chron as the early part of the Fortunian (Zhuravlev and Wood, 2018).
The development of ichnofossil assemblages as a reflection of evolutionary progress is subject of a number of articles. However, in most cases the age assignments are vague or based on co-occurring Small Shelly Fossils. Whether unmistakable arthropod traces of such ichnogenera as Rusophycus, Cruziana, Monomorphichnus etc. can be taken as a proof for an age corresponding to the uppermost Fortunian or even Cambrian Stage 2 remains open (e.g., Geyer and Landing, 2016; Mángano and Buatois, 2016).

\section{Cambrian Stage 2}

Small Shelly Fossils or Early Skeletal Fossils from pre-trilobitic Cambrian strata have been extensively studied during the 1970s, 1980s and 1990s in numerous regions. However, little agreement has been reached during that period about the possibilities of intercontinental correlation by means of such bilaterian skeletal elements. During the last two decades, a mild revival in the study such faunas, particularly mollusks, tommotiids and brachiopods, has featured some biostratigraphic potential, although limitations by facies and taxonomic problems due to oversplitting obscure the true ranges of many of the potential biostratigraphic indicators.

Although most SSFs are of provincial distribution, some taxa, such as Watsonella crosbyi, Aldanella attleborensis, Purella squamulosa, Anabarella plana and Lapworthella spp. have a relatively wide distribution and may contribute to an intercontinental correlation (e.g., Steiner et al., 2007; Li et al., 2011; Li, 2013; Parkhaev, 2014). Particularly $W$. crosbyi has been identified from South China, South Australia, Mongolia, the Siberian Platform, Avalonian North America, and France, albeit it is obvious that the local ranges recognized from these regions do not reflect the true ranges of the species. The FAD of $W$. crosbyi has been proposed as a candidate GSSP marker for defining the lower boundary of Stage 2 boundary (Li et al., 2011), but further calibration by biostratigraphically useful fossils (such Anabarella plana and Purella spp. below and Lapworthella spp. above) and nonbiostratigraphic correlation tools are needed.

The FADs of Watsonella crosbyi and Aldanella attleborensis can be tied to carbon isotopic signatures as particularly evident in northeastern Yunnan, South China, where $W$. crosbyi occurs just below a major positive $\delta^{13} \mathrm{C}$ excursion (termed ZHUCE by Zhu et al., 2006). Landing and Geyer (2012) proposed to use this $\delta^{13} \mathrm{C}$ positive excursion as a prime correlation tool for the base of Stage 2 .

Acritarchs have been regarded as biostratigraphically useful fossils in this stratigraphic as well, but the occurrences of the mostly cited Skiagia ornata (e.g., Moczydłowska and Zang 2006; Moczydłowska and Yin, 2012) subsequently has been suggested to depend largely on facies conditions (see discussions in Landing et al., 2013a).

\section{Cambrian Stage 3}

The onset of trilobites in earth history as the principle faunal elements and biostratigraphic indicators in the Cambrian is understood as an important step in biotic development. However, correlation of the oldest trilobite assemblages is proven to be extremely difficult because of (1) a distinct diachronism of the earliest appearance of tri- 
lobites in different regions, and (2) a yet unexplained pronounced provincialism that makes almost every earliest trilobite assemblage fairly unique. A few genera exist which have been suggested to have some intercontinental distribution, but they are so limited in their local stratigraphic ranges that their true biozones are poorly recognized (Palmer, 1998) or their generic assignment requires careful reexamination.

The oldest/lowest trilobites appear in many regions in strata that overlie unconformities. Most of these trilobite assemblages are found in facies that suggest shallow marine to nearshore deposition, and those biofacies are again characterized by endemic polymerid trilobites. Other fossils associated with these assemblages, such as archaeocyaths, molluscs, hyoliths, hyolithelminths, and other small shelly fossils, also have limited occurrences or show strong limitations to certain biofacies types, and thus have limited potential for intercontinental correlation.

These facts suggest that a series boundary at the first occurrence of trilobites will be inappropriate because it generally lacks the possibility of global biostratigraphic identification and correlation. Chemostratigraphic investigations revealed a carbon isotope excursion that occurred shortly after the FAD of trilobites (e.g., Brasier, 1993; Brasier et al., 1992, 1994), with a pronounced peak in the Repinaella Zone of the Siberian Platform (Brasier et al., 1994; Brasier and Sukhov, 1998). This $\delta^{13} \mathrm{C}$ appears to be recognizable as well in West Gondwana (Morocco) and possibly in Laurentia and is termed the EAREZE excursion. The EAREZE peak has been proposed as a prime correlation tool for the base of Series 2 and Stage 3 (Landing et al., 2013b).

Unfortunately, the FADs of trilobites in various regions are still erroneously interpreted in a number of cases. Prominent examples are the oldest trilobites in South China, which were once regarded as the oldest on earth (e.g., Luo, 1981; Zhang, 1987), but in fact are quite late arrivals. Yet, it appears that their true stratigraphic position is still not generally accepted. In addition, the correlation of the oldest/lowest Parabadiella huoi assemblage (concerning the incorrectly assumed synonymy of Parabadiella with Abadiella see Geyer, in press) from the platform facies belt of South China with a fauna in South Australia, from which the same trilobite species is identified, led to an erroneously much too early estimation of the age of the oldest trilobites in Australia as well (e.g., Betts et al., 2018; Paterson et al., 2019). A similarly incorrect assessment affects the age of the Schmidtiellus mickwitzi Zone in Baltica, which is triggered by its cooccurrence with the Skiagia ornata-Fimbriaglomerella membranacea acritarch assemblage (Moczydlowska, 1998; Schoenemann et al., 2017). Details of the correlation of the oldest trilobites in the key regions will be presented elsewhere.

In general, correlation of Stage 3 from South China and Australia is often hampered by an incomplete understanding of the biostratigraphy of key areas such as West Gondwana and western Avalonia and disputable interpretations such as in Maloof et al. $(2005,2010)$ (e.g. Betts et al., 2018; Paterson et al., 2019).

\section{Cambrian Stage 4}

The late early Cambrian (in the revised concept after the introduction of the Miaolingian Series and Wuliuan Stage) includes, or at least should include, strata that are traditionally assigned to the Calodiscus- and Serrodiscus-bearing beds in Avalonia as well as the Mediterranean sector of West Gondwana, holmiid-bearing strata in Baltica and also the strata with bergeronielline trilobites on the Siberian Platform and the adjacent fold-belts of central Asia. Due to the high position which was chosen for the base of the Miaolingian and Wuliuan, this stage also includes paradoxidine-bearing strata in West Gondwan, Avalonia and on the Siberian Platform, which were traditionally assigned to the "Middle Cambrian" (summarized in Geyer 2005).

This high position of the base of the Miaolingian and Wuliuan contributed to a skewed picture of Stage 4 when it comes to the situation in South China and Australia. A relatively high number of biozones have been recognized in the successions in South China (Fig. 1; see also Yuan et al., 2002), most of them correlating with strata that were traditionally regarded as Middle Cambrian in the European regions, and these zones obviously reflect a high frequency of modifications in the faunal assemblages. Nevertheless, it is almost certain that these zones cover only a relatively short period of time. Several of these zones correlate only with one or two zones recognized on the Siberian Platform, Morocco or southeastern Newfoundland. Nonetheless, recent developments show that levels within these "young zones were considered occasionally as suitable for designating a GSSP for the base of Stage 4 (e.g., Zhu et al., 2018). Particularly intriguing is that even the nomenclature of species characteristic of this interval is incompletely understood. Arthricocephalus chauveaui was brought into discussion in this context but the suggestions to use this species indicate uncertainties about its identity as Oryctocarella duyunensis sensu Peng et al. (2017) or the traditional, erroneous identification in most articles (e.g., Qian, 1980; Geyer and Peel, 2011; Yuan et al., 2002).

The correlation of this upper part of Stage 4 has been subject of a thorough study by Sundberg et al. (2016). However, some of its data have been widely ignored to date and have not been taken into serious consideration for the Miaolingian/Wuliuan boundary proposals and decision (e.g., Zhao et al., 2018, 2019). A recent study on the upper part of the traditional lower Cambrian in Scandinavia and Baltica in general (Cederström et al., accepted) suggests a revision of the biostratigraphic concept as well as a revision of the correlation into other regions. The data of both articles are incorporated in the present correlation chart.

A boundary at the FAD level of Redlichia or Olenellus must be regarded as impractical because neither can be identified with any certainty in the majority of continents. Both Redlichia and Olenellus form intricately subdivided clades with the different genera having their FADs at distinctly different stratigraphic levels (Sundberg et al., submitted).

Helpful for a correlation clearly below the late Arthricocephalus/ Oryctocarella levels is an assemblage characterised by fairly widespread eodiscoids in the upper part of the traditional early Cambrian. Species of this assemblage include Hebediscus attleborensis, Calodiscus schucherti, C. helena, Serrodiscus bellimarginatus, Triangulaspis vigilans, and T. annio (Fletcher, 1972; Robison et al., 1977; Geyer, 2005). As frequently noted before, the majority of these species have limited spatial occurrences, but their ranges show some regional overlap. A correlation of this "stratigraphical band subtended by associated taxa allows it to be identified in Baltica (Sweden), Avalonia (southeastern Newfoundland, New Brunswick, Welsh Borderlands), 


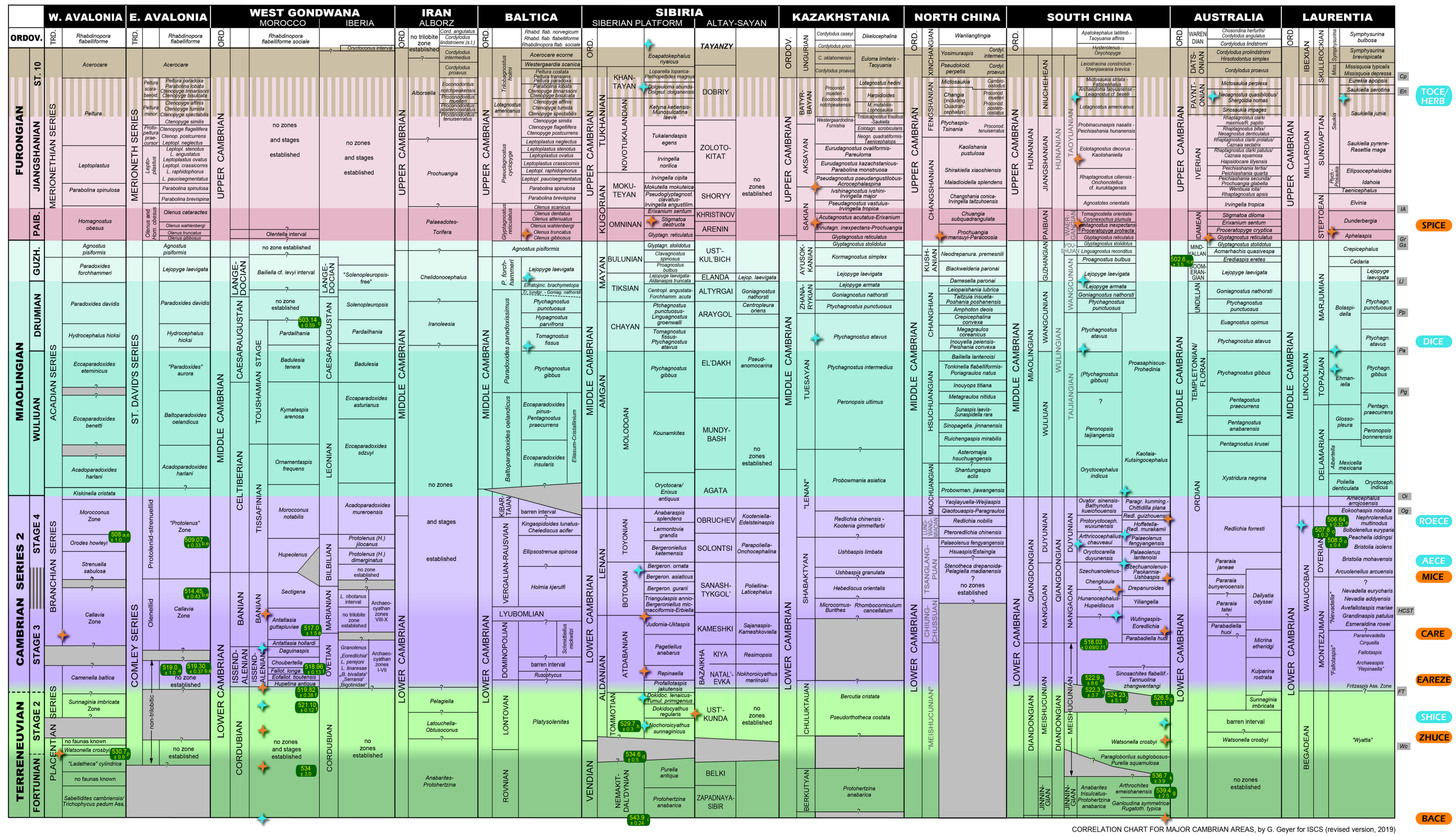


Figure 1. Correlation chart for the Cambrian biostratigraphic units of important regions/palaeocontinents with presently acknowledged regional series and stages as well as biostratigraphical units (slightly modified by the author in some cases). Colours indicate defined or suggested stages. Positions of correlation based on the FAD of accepted levels (discussed in the text) flagged at the right-hand margin; abbreviations: Wc, Watsonella crosbyi; FT, first occurrence of trilobites; HCST, Hebediscus attleborensis-Calodiscus lobatus-Serrodiscus-Triangulaspis band; Og, Ovatoryctocara granulata; Oi, Oryctocephalus indicus; Pg, Ptychagnostus gibbus; Pa, Ptychagnostus atavus; Pp, Ptychagnostus punctuosus; Ll, Lejopyge laevigata; Gs, Glyptagnostus stolidotus; Gr, Glyptagnostus reticulatus; IA, Irvingella in association with Agnostotes; En, Eoconodontus notchpeakensis; Cp, Cordylodus proavus. Significant positive carbon isotope peaks indicates by ochre stars, negative peaks by green stars. Radiometric age determinations from numerous authors (e.g., Bowring et al., 1993 ('); Landing et al., 1998 ( $)$ ), $2015(\mathcal{C})$, submitted (f); Zhu et al., 2009 (k); Wei et al., $2018(\mathrm{~m})$; Compston et al., $2008\left(^{g}\right)$; Harvey et al., 2011 (b); partly recalculated by Schmitz, 2012 ( ); Nagovotsin et al., 2015 ('); Rogov et al., 2015 ()); Perkins and Walshe, 1993 ("); Karlstrom et al., under review ( ); Isachsen et al., $1994{ }^{(')}$. Remarks on the columns: A number of stage names are used to date in a wrongly derived spelling. These orthographic mistakes are corrected (e.g., Botoman/Botomian; Delamarian/Delamaran; Dyerian/Dyeran; Marjumian/Marjuman; Topazian/Topazan). Baltica: The column for Baltica is dominated by the zones used in Sweden/Scandinavia, with an updated zonation for the Furongian as suggested by Terfelt et al. (2008). The early Cambrian stages are modified from Nielsen and Schovsbo (2011) using biostratigraphic results from Cederström et al. (accepted). Sibiria: "Sibiria is used as a name for the Palaeozoic continent, differing from "Siberia as the name for the modern-day geographic region. The chronostratigraphic units used in the column for the Siberian Platform is recombined from the established units (e.g., Lazarenko et al., 2011) and the revision suggested by Varlamov et al. (2013), which is not yet officially ratified. "Altay-Sayan" refers to the foldbelt region. The names for the subdivisions refer to the traditional "horizons" (горизон) which are not stages or any kind of chronostratigraphic units. The used units are from Korzhnev (2012) and Naimark and Pegel' (2017). The transcription of the names is revised. North China: Abandoned traditional series and stages which were originally transferred from South China are shown in grey for better orientation. South China: Decisions on GSSPs prompted renaming and (party) redefinitions on regional series and stages (Peng, 2009; National Commission Stratigraphy of China, 2014; Peng, 2018; Peng and Zhao, 2018), with revision of the established scheme. Due to better orientation and creation of homonyms the earlier scheme in shown in grey. Different biozones for the Fortunian through Drumian refer to differences between the platform and slope facies. The Parabadiella huoi Zone is spelled Abadiella huoi Zone in the modern schemes based on the erroneous assumption that Parabadiella is a junior synonym of Abadiella (see discussion in Geyer, in press). Laurentia: The column shows the traditional position of the lower boundary of the Ibexian Series and Skullrockian Stage. See also Babcock et al. (2011) for suggested internationalization of the Laurentian stratigraphy. Base of the Marjumian Stage indicated in the original definition (see Sundberg 2005), not as revised by Palmer (1998). Different biostratigraphic zonation used for the lower-middle Cambrian boundary interval reflect regional units.

West Gondwana (Spain, Morocco, Germany), various parts of the Siberian Platform and the Altay-Sayan foldbelt, and Kazakhstan. Such assemblages occur at the top of the Callavia broeggeri Zone in southeastern Newfoundland and the Callavia Zone in England, the Sectigena Zone in Morocco, the top of the Judomia and Bergeroniellus micmacciformis-Erbiella Zone in Siberia.

\section{Traditional lower-middle Cambrian boundary interval and Wuliuan Stage}

After two decades of discussions on the lower-middle Cambrian boundary, the ISCS introduced the Miaolingian Series and Wuliuan Stage (Zhao et al., 2018, 2019), defined by a GSSP in the Guizhou Province, South China, and based on the FAD of Oryctocephalus indicus. This species, first described from the Spiti area of Kashmir (Reed, 1910; Jell and Hughes, 1997), has been found in the Great Basin area just above the top of the Olenellus Zone (Sundberg and McCollum, 1997) and in the lower part of the Kaili Formation in the Guizhou Province (Zhao et al., 1996; Yuan et al., 1997; Sundberg et al., 2000). The utility of Oryctocephalus indicus as a global index fossil was corroborated by synonymizing the Siberian Oryctocephalus sibiricus with $O$. indicus although no general consensus about this identification has been achieved. The boundary level coincides moreor-less completely with the traditional lower-middle Cambrian boundaries in South China and Laurentia, but nowhere else. It is the highest considered possible level for the boundary so that in most regions traditional middle Cambrian strata now belong to Stage 4, including Paradoxides-bearing strata in Siberia, Avalonia and West Gondwana.
In addition, a reliable identification of the boundary is only possible in South China, Laurentia, and Sibiria (if the synonymy of $O$. indicus with $O$. sibiricus is accepted), whereas on most other Cambrian continents the boundary is not recognizable with any certainty.

A level that would have been much more appropriate for a global boundary has been discussed as an alternative GSSP candidate. It is characterized by the FAD of Ovatoryctocara granulata, known from the Siberian Platform, Greenland and Avalonian Newfoundland. Disputed occurrences have been reported from South China, where former identifications of the species were revised and the specimens are now suggested to represent a new species, Ov. sinensis (Zhao et al., 2015). On the Siberian Platform, Ov. granulata was used as an index fossil for the Amgan Stage (now Molodoan) and thus for the traditional lower-middle Cambrian boundary in this region. A number of trilobite assemblages with eodiscoid and polymerid trilobite genera occur around the $O v$. granulata level with potential for long distance correlation. Such trilobite taxa include, e.g., Cobboldites spp., Protolenus (Protolenus) spp., Latoucheia (Latoucheia) spp., Hamatolenus spp., Acadoparadoxides spp., Conomicmacca, and Bathynotus, known from western Avalonia, the UK, Poland, Spain, Morocco, Germany, Turkey, and Siberia. Correlation of these assemblages has been dealt with in a number of publications (Geyer, 1998; Geyer and Peel, 2011), and the (relatively minor) differences in fine-scale correlation indicate problems related to taxonomic concepts as discussed by Geyer (1998). It should be considered, whether this level should define a substage of Stage 4 to allow a better characterization of the stratigraphic position of strata in Siberia, Baltica, Avalonia and West Gondwana on a global scale.

Ptychagnostus gibbus is a widespread agnostoid species in the 
later/upper part of the Wuliuan, distributed in Antarctica, Australia, Kazakhstan, the Siberian Platform, Poland, Sweden, Norway, the UK, Greenland, Newfoundland, and the United States. Nevertheless, its first appearance lies on top of a surface that indicates a major sea level rise. Consequently, the FAD of $P$. gibbus is usually marked by a disconformity. The species is used as an index fossil on Baltica, the Siberian Platform, South China, Australia, and Laurentia, and forms the basal zone of the Paradoxides paradoxissimus Stage in Scandinavia. The species is frequently accompanied by similarly widespread agnostoids so that this level is useful for a subglobal correlation of the gibbus level as a potential auxiliary upper substage of the Wuliuan.

\section{Drumian Stage}

The base of the Ptychagnostus atavus Zone is believed to mark a significant faunal change, which is correlated in Laurentia with that at the base of the Bolaspidella Zone. However, this is not a biomere boundary as defined by Palmer (1981, 1998) and Sundberg (1994). The Ptychagnostus atavus Zone defines the base of the Marjuman Stage in Laurentia (Ludvigsen and Westrop, 1985), and its FAD in the Drum Mountains, Utah, was thus chosen to define the base of the Drumian Stage (Babcock et al., 2007). Ptychagnostus atavus is a widespread species known from the Laurentian United States and Canada, Greenland, Australia, Vietnam, South China, North Korea, the Siberian Platform, Sweden, Norway and the UK. The base of the P. atavus Zone corresponds with the base of the Floran Stage in Australia (Öpik, 1967). A significant negative $\delta^{13} \mathrm{C}$ excursion (termed DICE) has been identified from the Ptychagnostus atavus Zone and correlative levels (e.g., Ahlberg et al., 2009; Howley and Jiang, 2010) although its magnitude and temporal extent appears to vary considerably.

A second index fossil that allows a subglobal correlation within the Drumian is Ptychagnostus punctuosus, described from Australia, New Zealand, South China, the Tarim Platform, Kazakhstan, the Siberian Platform, Sweden, Norway, the UK, Greenland, Avalonian and Laurentian Canada and the United States. Its occurrence is frequently used to define an interval-zone. It also defines the base of the Undillan Stage in Australia, the Zhanarykian Stage in Kazakhstan, and the Wangcunian in South China (Peng et al., 1998). It should be noted that the base of the Wangcunian was revised to lie at the FAD of Ptychagnostus atavus (Peng, 2009, 2018; Zhu et al., 2018) so that the present-day Wangcunian is a junior homonym of the original Wangcunian.

\section{Guzhangian Stage}

The base of the Lejopyge laevigata Zone was chosen as the base of the Guzhangian Stage (Peng et al., 2009) although the occurrence of Lejopyge laevigata is more limited than those of other late middle Cambrian trilobites and conodonts from this interval. Nevertheless, those species (e.g., the trilobites Opsidiscus bilobatus, Oidalagnostus trispinifer, Diplagnostus planicauda, Hypagnostus brevifrons, Peronopsis insignis, and the conodonts Gapparodus bisulcatus, Hertzina carinata, Prosagittodontus dahlmani) permit a relatively precise cor- relation into other deeper water successions. Lejopyge laevigata occurs in Australia, South China, Denmark, Greenland, India, Kazakhstan, Turkestan, the Siberian Platform, Sweden, Norway, northern Poland, and USA and is used as formal index fossil in Scandinavia, Siberia, Australia, Kazakhstan and China. It defines the base of the Boomerangian Stage in Australia and the Ayusokkanian Stage in Kazakhstan.

The index fossil of the base of the traditional Upper Cambrian is Agnostus pisiformis. It appears to be restricted to Sweden, Norway, Poland, England, Novaya Zemlya, and southeastern Newfoundland. Nevertheless, it characterizes a zone near the top of the Guzhangian. To avoid problems with the limited occurrence and related uncertainties, Peng and Robison (2000) suggested the use of a Linguagnostus reconditus Zone to replace the Agnostus pisiformis Zone.

Glyptagnostus stolidotus has a similar but slightly less frequent occurrence than G. reticulatus. It is known from Antarctica, Australia, South China, Kazakhstan, the Siberian Platform, the Altay-Sayan Foldbelt and the USA, and used as an index fossil in Siberia, Kazakhstan, South China, and Australia. This zone underlies the Glyptagnostus reticulatus Zone at the base of the Furongian and Paibian and thus corroborates a recognition of that level.

\section{Paibian Stage}

The Paibian Stage and Furongian Series starts with the FAD of Glyptagnostus reticulatus. The zone of this agnostoid trilobite is one of the most widely recognizable horizons. The species has been identified from Antarctica (Ellsworth Mountains), Australia, South China, South Korea, Kazakhstan (Lesser Karatau), the Siberian Platform, Norway, Denmark, Sweden, UK, Canada, the USA, and Argentina, and is used as a zonal index fossil in Siberia, Kazakhstan, South China, Australia, and Laurentia. The base of the zone coincides with a significant faunal change that is expressed, e.g., by the boundary between the Marjumiid and the Pterocephaliid biomeres in Laurentia, the base of the Idamean Stage in Australia, the base of the Sakian Stage in Kazakhstan), and the base of the Kugorian Superstage in Siberia. Correlation within the stage is enabled by a number of additional widespread agnostoids.

A chemostratigraphic correlation is provided by the subglobally recognized SPICE positive $\delta^{13} \mathrm{C}$ excursion (e.g., Saltzman et al., 2000; Kouchinsky et al., 2008; Ahlberg et al., 2009; Ng et al., 2013; Schmid et al., 2018; Pruss et al., 2019).

\section{Jiangshanian Stage}

The co-occurrence of the early species of the trilobites genus Irvingella, such as I. tropica, with species of Agnostotes in a number of regions emphasizes has been recognized as a reliable correlation horizon, particularly because the index species are postdated by younger species of Irvingella (e.g., I. major and I. perfecta). This situation led to the GSSP for the base of the Jiangshanian Stage near Duibian, Zhejiang Province, China, where the FAD of Agnostotes orientalis coincides with the first appearance of Irvingella angustilimbata (Peng et al., 2009).

Irvingella occurs in Australia, Vietnam, South China, South Korea, 
The Tarim Platform, Kazakhstan, the Siberian Platform, Novaya Zemlya, Sweden, the UK, Canada, and the USA, Argentina, and possibly Antarctica. In Laurentia it ranges across the Steptoean-Sunwaptan Stage boundary; in Australia it defines the lower boundary of the Iverian Stage. Agnostotes (including Pseudoglyptagnostus and Glyptagnostotes) occurs in Australia, South China, South Korea, the Tarim Platform, Kazakhstan, the Siberian Platform, Canada, and in the USA. In a significant number of regions Irvingella and Agnostotes co-occur and have been used as zonal index fossils.

The Jiangshanian belongs to one of the most finely subdivided intervals in earth history. A large number of trilobite zones are established in regions such as Australia, South China, the Maly Karatau range in Kazakhstan or Scandinavia. However, most of them are regional schemes in which variations highly diverse assemblages contributes to an apparent rapid turnover that should not be confused with evolutionary changes.

\section{Cambrian Stage 10}

Two alternative solutions have been suggested for the base of Cambrian Stage 10. A proposal for a GSSP of the base of the stage is based on the FAD of agnostoid Lotagnostus americanus, with a suggested location in the Hunan Province, China, alternatively on the Siberian Platform (Peng et al., 2014). Controversy took place on the taxonomy of this species or clade, and the acceptance of a broad synonymisation of these forms ( $L$. americanus, L. trisectus; see Westrop et al., 2011; Peng et al., 2015) strongly affects the value of this level and its correlation. The FAD of Lotagnostus americanus (in broad sense) lies about two conodont zones below the FAD of Eoconodontus notchpeakensis (depending on the regional biostratigraphic resolution), which has been suggested as a candidate level as well, based on finely studied biostratigraphy of conodonts.

The FAD of Eoconodontus notchpeakensis has been identified in sections of western Utah, proposed to serve as the GSSP (Miller et al., 2006, 2018). The species is known from many facies in Laurentia and occurs in agnostoid biofacies in South China as well as in slope deposits in Kazakhstan. The Utah conodont biozonation includes nine zones and subzones which can be correlated globally through the entire interval of proposed Stage 10.

The suggested stage can also be bracketed by the HERB event, a high-amplitude negative carbon-isotope excursion that coincides with the Eoconodontus notchpeakensis Subzone of the Eoconodontus Zone. This carbon isotope excursion has been identified in Argentina, Australia, China, Sweden, Texas, and Utah, but vacillates in significance (e.g., Ripperdan, 2002; Zuo et al., 2018). The HERB event and the TOCE (originally suggested to lie near the base of the Ordovician) are now generally regarded as the representing same fluctuation in ocean chemistry. No negative $\delta^{13} \mathrm{C}$ excursion is recorded above the HERB peak in North America (Miller et al., 2006, 2011). This is the N3 peak of Li et al. (2017) registered in South China.

\section{Conclusions}

Global chronocorrelation within the Cambrian has made signifi- cant progress during the last three decades, leading to a mostly well accepted subdivision of the period into epochs and ages. Pending GSSPs for the remaining informal Series 2 and Stages 2, 3, 4, and 10 have a fair potential for global recognition. However, a major goal of the Cambrian community will be the recognition of regional markers that allow a fine-scale correlation between all major Cambrian continents. Fossil assemblages and physical markers that allow a reliable correlation need to be recognised in continents other than the wellstudied continents South China, Sibiria, Baltica, and Laurentia. It appears to be helpful if such correlation levels would be formally recognized and noted in correlation charts such as the one presented herein (Figure 1) and possible coded appropriately.

\section{Acknowledgments}

This article was made possible by research grant GE 547/22-1 of the Deutsche Forschungsgemeinschaft (DFG). An earlier version of the chart was circulated in 1999 among members of the International Subcommission on Cambrian Stratigraphy and merited from resulting criticism and suggestions by Peng S.C. (Nanjing), M. Moczydłowska (Uppsala), Zhu M.Y. (Nanjing), A.Yu. Zhuravlev and A.Yu. Rozanov (both Moscow), A.R. Palmer (Boulder), F.A. Sundberg (Washington), and T.V. Pegel' (Novosibirsk). I thank E.B. Naimark (Moscow), F.A. Sundberg (Phoenix, AZ) and A.Yu Zhuravlev (Moscow) for additional data. I also thank two anonymous reviewers who provided diligent reviews on the manuscript which substantially improved the text.

\section{References}

Ahlberg, P., Axheimer, N., Babcock, L.E., Eriksson, M.E., Schmitz, B., and Terfelt, F., 2009, Cambrian high-resolution biostratigraphy and carbon isotope chemostratigraphy in Scania, Sweden: first record of SPICE and DICE excursion in Scandinavia. Lethaia, v. 42, pp. 2-16.

Babcock, L.E., Peng, S.C., Geyer, G., and Shergold, J.H., 2005, Changing perspectives on Cambrian chronostratigraphy and progress toward subdivision of the Cambrian System. Geosciences Journal, v. 9, pp. 101-106.

Babcock, L.E., Robison, R.A., Rees, M.N., and Peng, S.C., 2007, The global boundary stratotype section and point (GSSP) of the Drumian Stage (Cambrian) in the Drum Mountains, Utah, USA. Episodes, v. 30, pp. 85-95.

Babcock, L.E., Robison, R.A., Peng, S.C., 2011, Cambrian stage and series nomenclature of Laurentia and the developing global chronostratigraphic scale. Museum of Northern Arizona Bulletin, v. 67, pp. $12-26$.

Betts, M.J., Paterson, J.R., Jacquet, S.M., Andrew, A.S., Hall, P.A., Jago, J.B., Jagodzinski, E.A., Preiss, W.V., Crowley, J.L., Brougham, T., Mathewson, C.B., García-Bellido, D.C., Topper, T.P., Skovsted, C.B., and Brock, G.A., 2018, Early Cambrian chronostratigraphy and geochronology of South Australia. Earth-Science Reviews, v. 185, pp. 498-543.

Bowring, S.A., Grotzinger, J.P., Isachsen, C.E., Knoll, A.H., Pelechaty, S.M., and Kolosov, P., 1993, Calibrating rates of Early Cambrian evolution. Science, v. 261, pp. 1293-1298.

Brasier, M.D., 1993, Towards a carbon isotope stratigraphy of the Cambrian System: potential of the Great Basin succession. In: Hallwood, E.A., and Kidd, R. B. (Eds.), High Resolution Stratigraphy, Geological 
Society Special publication, no. 70, pp. 341-350.

Brasier, M.D., and Sukhov, S.S., 1998, The falling amplitude of carbon isotopic oscillations through the Lower to Middle Cambrian: northern Siberia data. Canadian Journal of Earth Sciences, v. 35, pp. 353-373.

Brasier, M.D., Anderson, M.M., and Corfield, R.M., 1992, Oxygen and carbon isotope stratigraphy of early Cambrian carbonates in southeastern Newfoundland and England. Geological Magazine, v. 129, pp. 265-279.

Brasier, M.D., Rozanov, A.Yu., Zhuravlev, A.Yu., Corfield, R.M., and Derry, L.A., 1994, A carbon isotope reference scale for the Lower Cambrian succession in Siberia: report of IGCP Project 303. Geological Magazine, v. 131, pp. 767-783.

Cai, Y., Xiao, S., Li, G., and Hua, H., 2019, Diverse biomineralizing animals in the terminal Ediacaran Period herald the Cambrian explosion. Geology, https://doi.org/10.1130/G45949.1.

Cederström, P., Geyer, G., Ahlberg, P., Nilsson, C.A., and Ahlgren, J., accepted. Ellipsocephalid trilobites from Cambrian Series 2 and Stage 4 in Scania, Sweden: taxonomy, morphological plasticity and biostratigraphic significance. Fossils and Strata.

Chen, D.Z., Zhou, X.Q., Fu, Y., Wang, J.G., and Yan, D.T., 2014, New U$\mathrm{Pb}$ zircon ages of the Ediacaran-Cambrian boundary strata in South China. Terra Nova, v. 27, 62-68.

Compston, W., Zhang, Z., Cooper, J.A., Ma, G., and Jenkins, R.J.F., 2008, Further SHRIMP geochronology on the Early Cambrian of South China. American Journal of Science, v. 308, pp. 399-420.

Fletcher, T.P., 1972, Geology and Lower to Middle Cambrian trilobite faunas of southwest Avalon, Newfoundland. Part Two. Unpubl. Ph. D. thesis, University of Cambridge, $295 \mathrm{pp}$.

Geyer, G., 1998, Intercontinental, trilobite-based correlation of the Moroccan early Middle Cambrian. Canadian Journal of Earth Sciences, v. 35, pp. 374-401.

Geyer, G., 2005, The base of a revised Middle Cambrian: are suitable concepts for a series boundary in reach? Geosciences Journal, v. 9, pp. 81-99.

Geyer, G., in press, A critical evaluation of the Resserops clade (Trilobita: Despojulsiidae, early Cambrian) with remarks on related redlichiacean families. Freiberger Forschungshefte, Paläontologie, Stratigraphie, Fazies, v. 25.

Geyer, G., and Landing, E., 2016, The Precambrian-Phanerozoic and Ediacaran-Cambrian boundaries: a historical approach to a dilemma. In: Brasier, A. T., Mcllroy, D., and McLoughlin, N. (Eds.), Earth System Evolution and Early Life: a Celebration of the Work of Martin Brasier. Geological Society, London, Special Publications, v. 448, pp. 311-349.

Geyer, G., and Peel, J.S., 2011, The Henson Gletscher Formation, North Greenland, and its bearing on the global Cambrian Series 2-Series 3 boundary. Bulletin of Geosciences, v. 86, pp. 465-534.

Geyer, G., and Shergold, J.H., 2000, The quest for internationally recognized divisions of Cambrian time. Episodes, v. 23, pp. 188-195.

Harvey, T.H.P., Williams, M., Condon, D.J., Wilby, P.J., Siveter, D.J., Rushton, A.W.A., Leng M.J., and Gabbott, S.E., 2011, A refined chronology for the Cambrian succession of southern Britain. Journal of the Geological Society, v. 168, pp. 705-716.

Howley, R.A., and Jiang, G.Q., 2010, The Cambrian Drumian carbon isotope excursion (DICE) in the Great Basin, western United States). Palaeogeography, Palaeoclimatology, Palaeoecology, v. 296, pp. 138-150.

Isachsen, C.E., Bowring, S.A., Landing, E., and Samson, S.D., 1994, New constraint on the division of Cambrian time. Geology, v. 22, pp. 496498.

Jell, P.A., and Hughes, N.C., 1997, Himalayan Cambrian trilobites. Special Papers in Palaeontology, v. 58, pp. 1-113.

Karlstrom, K.E., Mohr, M.T., Schmitz, M.D., Sundberg, F.A., Rowland, S., Hagadorn, J., Foster, J.R., Crossey, L.J., Dehler, C., and Blakey, R., under review, Redefining the Tonto Group of Grand Canyon and recalibrating the Series 2-Miaolingian Epoch boundary of the Cambrian timescale. Geology.

Korzhnev, V.N., 2012, Stratigrafiya kembriyskikj otlozheniy severo- vostochnoy chasti Gornogo Altaya. Vestnik Tomskogo gosudarstvennogo universitet, Geologiya, 2012, pp. 196-203.

Kouchinsky, A., Bengtson, S., Gallet, Y., Korovnikov, I., Pavlov, V., Runnegar, B., Shields, G., Veizer, J., Young, E., and Ziegler, K., 2008, The SPICE carbon isotope excursion in Siberia: a combined study of the upper Middle Cambrian-lowermost Ordovician Kulyumbe River section, northwestern Siberian Platform. Geological Magazine, v. 145, pp. 609-622.

Landing, E., and Geyer, G., 2012, Misplaced faith - limitations of the first appearance datum (FAD) in chronostratigraphy and proposal of more robust Lower Cambrian correlation standards. Journal of Guizhou University (Natural Science), v. 29, pp. 170-171.

Landing, E.L., Bowring, S.A., Davidek, K.L., Westrop, S.R., Geyer, G., and Heldmaier, W., 1998, Duration of the Early Cambrian: U-Pb ages of volcanic ashes from Avalon and Gondwana. Canadian Journal of Earth Sciences, v. 35, pp. 329-38.

Landing, E., Peng, S.C., Babcock, L.E., Geyer, G., and MoczydlowskaVidal, M., 2007, Global standard names for the lowermost Cambrian series and stage. Episodes, v. 30, pp. 283-289.

Landing, E., Geyer, G., Brasier, M.D., and Bowring, S.A., 2013a, Cambrian Evolutionary Radiation: Context, correlation, and chronostratigraphy-overcoming deficiencies of the first appearance datum (FAD) concept. Earth Science Reviews, v. 123, pp. 133-172.

Landing, E., Geyer, G., Maloof, AC., Brasier, M.D., and Bowring, S.A., 2013b, Proposed GSSP (Global Stratotype Section and Point) for the Lenaldanian Series and Zhurinskyan Stage (=informal Cambrian Series 2 and Stage 3; upper part of the traditional lower Cambrian). Proposal to the International Subcommission on Cambrian Stratigraphy, 52 pp.

Landing, E., Geyer, G., Buchwaldt, E., and Bowring, S.A., 2015, Geochronology of the Cambrian: a precise Middle Cambrian U-Pb zircon date from the German margin of West Gondwana. Geological Magazine, v. 152, pp. 28-40.

Landing, E., Schmitz, M., Geyer, G., Trayler, R.B., and Bowring, S.A., submitted. Precise Early Cambrian U-Pb zircon dates bracket the oldest trilobites and archaeocyaths in Moroccan West Gondwana. Geological Magazine.

Lazarenko, N.P., Gogin, I.Ya., and Abaimova, G.P., 2011, The KhosNelege River section of the Ogon'or Formation: a potential candidate for the GSSP of Stage 10, Cambrian System. Bulletin of Geosciences, v. 86, pp. $555-568$.

Li, G.X., 2013, How to define the lower boundary of the Cambrian Stage 2: A biostratigraphic marker or a geochemical one? In: Lindskog, A., and Mehlqvist, K. (Eds.), International Geological Correlation Programme. Project 591 "The Early to Middle Paleozoic Revolution". Proceedings of the 3rd IGCP 591 Annual Meeting. Department of Geology, Lund University, pp. 179-180.

Li, G.X., Zhao, X., Gubanov, A., Zhu, M.Y. and Na, L., 2011, Early Cambrian mollusc Watsonella crosbyi: a potential GSSP index fossil for the Base of the Cambrian Stage 2. Acta Geologica Sinica, v. 85, pp. 309 319.

Li, D.D., Zhang, X.L., Chen, K.F., Zhang, G.J., Chen, X.Y., Huang, W., Peng, S.C., and Shen, Y.N., 2017, High-resolution C-isotope chemostratigraphy of the uppermost Cambrian stage (Stage 10) in South China: implications for defining the base of Stage 10 and palaeoenvironmental change. Geological Magazine, v. 143, pp. 1232-1243.

Ludvigsen, R., and Westrop, S.R., 1985, Three new Upper Cambrian stages for North America. Geology, v. 13, pp. 139-143.

Luo, H.L., 1981, A synopsis of the Cambrian system in Yunnan, China. In: Taylor, M.E. (Ed.), Short Papers for the Second International Symposium on the Cambrian System, Golden 1981, Open File Rept. 81-743, pp. 123-125.

Maloof, A.C., Schrag, D.P., Crowley, J.L., and Bowring, S.A., 2005, An expanded record of Early Cambrian carbon cycling from the Anti-Atlas Margin, Morocco. Canadian Journal of Earth Sciences, v. 42, pp. 
2195-2216.

Maloof, A.C., Ramezani, J., Bowring, S.A., Fike, D.A., Porter, S.M., and Mazouad, M., 2010, Constraints on early Cambrian carbon cycling from the duration of the Nemakit-Daldynian-Tommotian boundary $\delta^{13} \mathrm{C}$ shift, Morocco. Geology, v. 38, pp. 623-626.

Mángano, M.G., and Buatois, L.A., 2016, The Cambrian Explosion. In: Mángano, M.G. and Buatois, L.A. (eds.), The Trace-Fossil Record of Major Evolutionary Events. Volume 1: Precambrian and Paleozoic. Topics in Geobiology, no. 39, Springer Science and Business Media, Dordrecht, pp. 73-126.

Miller, J.F., Ethington, R.L., Evans, K.R., Holmer, L.E., Loch, J.D., Popov, L.E., Repetski, J.E., Ripperdan, R.L., and Taylor, J.F., 2006, Proposed stratotype for the base of the highest Cambrian stage at the first appearance datum of Cordylodus andresi, Lawson Cove section, Utah, USA. Palaeoworld, v. 15, pp. 384-405.

Miller, J.F., Evans, K.R., Freeman, R.L., Ripperdan, R.L., and Taylor, J.F., 2011, Proposed stratotype for the base of the Lawsonian Stage (Cambrian Stage 10) at the First Appearance Datum of Eoconodontus notchpeakensis (Miller) in the House Range, Utah, USA. Bulletin of Geosciences, v. 86, pp. 595-620.

Miller, J.F., Evans, K.R., Freeman, R.L., Loch, J.D., Ripperdan, R.L., and Taylor, J.F., 2018. Combining biostratigraphy, carbon isotope stratigraphy and sequence stratigraphy to define the base of Cambrian Stage 10 . Australasian Palaeontological Memoirs, v. 51, pp. 19-64.

Moczydłowska, M., 1998, Cambrian acritarchs from Upper Silesia, Poland-Biochronology and tectonic implications. Fossils and Strata, v. 46, pp. 1-121.

Moczydlowska, M., and Zang, W.L., 2006, The Early Cambrian acritarch Skiagia and its significance for global correlation. Palaeoworld, v. 15, pp. 328-347.

Moczydlowska, M., and Yin, L.M., 2012, Phytoplanktic microfossils record in the lower Cambrian and their contribution to stage chronostratigraphy. Journal of Guizhou University (Natural Science), v. 29, pp. 49-58.

Nagovitsin, K.E., Rogov, V.I., Marusin, V.V., Karlova, G.A., Kolesnikov, A.V., Bykova, N.V., and Grazhdankin, D.V., 2015, Revised Neoproterozoic and Terreneuvian stratigraphy of the Lena-Anabar Basin and north-western slope of the Olenek Uplift, Siberian Platform. Precambrian Research, v. 270, pp. 226-245.

Naimark, E.B., and Pegel', T.V., 2017, Revision of the Cambrian Agnostina (Trilobita?) from Russia. Paleontological Journal, v. 51, pp. 11671248.

National Commission Stratigraphy of China, 2014, Stratigraphical guide of China and its explanation (2014). Geological Publishing House, Beijing, pp. 1-62. (in Chinese)

Ng, T.W., Yuan, J.L., and Lin, J.P., 2013, The North China Steptoean positive carbon isotope excursion and its global correlation with the base of the Paibian Stage (early Furongian Series), Cambrian. Lethaia, v. 47, pp. 153-164.

Nielsen, A.T., Schovsbo, N.H., 2011. The Lower Cambrian of Scandinavia: Depositional environment, sequence stratigraphy and palaeogeography. Earth-Science Reviews, v. 107, pp. 207-310.

Öpik, A.A., 1967, The Ordian Stage of the Cambrian and its Australian Metadoxididae. Bureau of Mineral Resources of Australia, Bulletin, no. 92, pp. 133-170.

Palmer, A.R., 1981, On the correlatability of the Grand Cycle tops. In: Taylor, M.E. (Ed.), Short Papers of the Second International Symposium on the Cambrian System, Golden 1981. United States Geological Survey, Open-File Report 81-743, pp. 156-159.

Palmer, A.R., 1998, A proposed nomenclature for stages and series for the Cambrian of Laurentia. Canadian Journal of Earth Sciences, v. 35, pp. 323-328.

Parkhaev, P.Yu. 2014, On the stratigraphy of Aldanella attleborensispotential index species for defining the base of Cambrian Stage 2. In: Zhan, R.B., and Huang, B. (Eds.), IGCP Project 591 Field Workshop
2014 in conjunction with International Subcommission on Silurian Stratigraphy (ISSS) International Subcommission on Ordovician Stratigraphy (ISOS) and International Subcommission on Cambrian Stratigraphy (ISCS), Extended Summary. Nanjing University Press, Nanjing, pp. 102-105.

Paterson, J.R., Edgecombe, G.D., and Lee, M.S.Y., 2019, Trilobite evolutionary rates constrain the duration of the Cambrian explosion. PNAS, 6 pp., www.pnas.org/cgi/doi/10.1073/pnas.1819366116.

Peng, S.C., 2009, The newly-developed Cambrian biostratigraphic succession and chronostratigraphic scheme for South China. Chinese Science Bulletin, v. 54, pp. 4161-4170.

Peng, S.C., 2018. Cambrian. In: National Committee on Stratigraphy of China (Ed.), Explanation of the Stratigraphic Chart of China (2014). Geological Press, Beijing, pp. 73-100.

Peng, S.C., and Robison, R. A., 2000, Agnostoid biostratigraphy across the Middle-Upper Cambrian boundary in China. Journal of Paleontology, Memoir, v. 38, pp. 103-107.

Peng, S.C., and Zhao, Y.L., 2018, The proposed Global Standard Stratotype-section and Point (GSSP) for the conterminous base of Miaolingian Series and Wuliuan Stage at Balang, Jianhe, Guizhou, China was ratified by IUGS. Journal of Stratigraphy, v. 42, pp. 325-327.

Peng, S.C., Zhou, Z.Y., and Lin, T.R., 1998, Late Middle-Late Upper Cambrian chronostratigraphy of China. Fourth Field Conference of the Cambrian Stage Subdivision Working Group, International Subcommission on Cambrian Stratigraphy, Abstracts, p. 20.

Peng, S.C., Babcock, L.E., Robison, R.A., Lin, H.L., Rees, M.N., and Saltzman, M.R., 2004, Global Standard Stratotype Section and Point (GSSP) of the Furongian Series and Paibian Stage (Cambrian). Lethaia, v. 37, pp. 365-379.

Peng, S.C., Babcock, L.E., Zuo, J., Lin, H.L., Zhu, X., Yang, X., Robison, R.A., Qi, Y., Bagnoli, G., and Chen, Y.Y., 2006, Proposed GSSP for the base of Cambrian Stage 7, coinciding with the first appearance of Lejopyge laevigata, Hunan, China. Palaeoworld, v. 15, pp. 367-383.

Peng, S.C., Babcock, L.E., Zuo, J., Lin, H., and Zhu, X., 2009, The global boundary stratotype section and point (GSSP) of the Guzhangian Stage (Cambrian) in the Wuling Mountains, northwestern Hunan, China. Episodes, v. 32, pp. 41-55.

Peng, S.C., Babcock, L.E., and Zuo, J.X., 2012, The Global Standard Stratotype-Section and Point (GSSP) for the Base of the Jiangshanian Stage (Cambrian: Furongian) at Duibian, Jiangshan, Zhejiang, Southeast China. Episodes, v. 35, pp. 462-477.

Peng, S., Babcock, L.E., Zhu, X., Zuo, J., and Dai, T., 2014, A potential GSSP for the base of the uppermost Cambrian stage, coinciding with the first appearance of Lotagnostus americanus at Wa'ergang, Hunan, China. GFF, v. 136, pp. 208-213.

Peng, S.C., Babcock, L.E., Zhu, X., Terfelt, F., and Dai, T., 2015, Intraspecific variation and taphonomic alteration in the Cambrian (Furongian) agnostoid Lotagnostus americanus: new information from China. Bulletin of Geosciences, v. 90, pp. 281-306.

Peng, S.C., Babcock, L.E., Zhu, X.J., Lei, Q.P., and Dai, T., 2017, Revision of the oryctocephalid trilobite genera Arthricocephalus Bergeron and Oryctocarella Tomashpolskaya and Karpinski (Cambrian) from South China and Siberia. Journal of Paleontology, v. 91, pp. 933-959.

Perkins, C., and Walshe, J.L., 1993, Chronology of the Mount Read Volcanics, Tasmania, Australia. Economic Geology, v. 88, pp. 1176-1197.

Pruss, S.B., Jones, D.S., Fike, D.A., Tosca, N.J., and Wignall, P.B., 2019, Marine anoxia and sedimentary mercury enrichments during the Late Cambrian SPICE event in northern Scotland. Geology, v. 47, pp. 475-487.

Qian, Y.Y., 1980, Superfamily Oryctocephalacea Beecher, 1897. In: Zhang, W.T., Lu, Y.H., Zhu, Z.L., Qian, Y.Y., Lin, H.L., Zhou, Z.Y., Zhang, S.G., and Yuan, J.L., Cambrian Trilobite Faunas of Southwestern China. Palaeontologia Sinica, no. 159, new series B, v. 16, pp. 266-283, 425, 433-434. (In Chinese)

Reed, F.R.C., 1910, The Cambrian fossils of Spiti. Palaeontologia Indica, Series 15, v. 7, pp. 1-70. 
Ripperdan, R., 2002, The HERB event: end of the Cambrian carbon cycle paradigm? Geological Society of America Abstracts with Programs, v. 34, p. 413.

Robison, R.A., Rosova, A.V., Rowell, A.J., and Fletcher, T. P., 1977, Cambrian boundaries and divisions. Lethaia, v. 10, pp. 257-262.

Rogov, V.I., Karlova, G.A., Marusin, V.V., Kochnev, B.B., Nagovitsin, K.E., and Grazhdankin, G.V., 2015, Duration of the first biozone in the Siberian hypostratotype of the Vendian. Russian Geology and Geophysics, v. 56, pp. 573-583.

Saltzman, M.R., Runnegar, B., Lohman, K.C., 1998, Carbon isotope stratigraphy of Upper Cambrian (Steptoean Stage) sequences of the eastern Great Basin: record of a global oceanographic event. Geological Society American Bulletin, v. 110, pp. 285-297.

Saltzman, M.R., Ripperdan, R.L., Brasier, M.D., Lohmann, K.C., Robison, R.A., Chang, W.T., Peng, S.C., Ergaliev, E.K., and Runnegar, B., 2000, A global carbon isotope excursion (SPICE) during the Late Cambrian: relation to trilobite extinctions, organic-matter burial and sea level. Palaeogeography, Palaeoclimatolology, Palaeoecology, v. 162, pp. 211-223.

Schoenemann, B., Pärnaste, H., and Clarkson, E.N.K., 2017, Structure and function of a compound eye, more than half a billion years old. PNAS, 6 pp., www.pnas.org/cgi/doi/10.1073/pnas.1716824114.

Shergold, J., and Geyer, G., 2001, The International Subcommission on Cambrian Stratigraphy: Progress Report 2001. Acta Palaeontologica Sinica, 40, Suppl., pp. 1-3.

Schmid, S., Smith, P.M., and Woltering, M., 2018, A basin-wide record of the Late Cambrian Steptoean positive carbon isotope excursion (SPICE) in the Amadeus Basin, Australia. Palaeogeography, Palaeoclimatology, Palaeoecology, v. 508, pp. 116-128.

Schmitz, M.D., 2012, Appendix 2 - Radiometric ages used in GTS2012. In: Gradstein, F.M., Ogg, J.G., Schmitz, M.D., and Ogg, G.M. (Eds.), The Geologic Time Scale 2012, Vol. 1. Elsevier B.V., Amsterdam, pp. 1045-1082.

Steiner, M., Li, G.X., Qian, Y., Zhu, M.Y., and Erdtmann, B.D., 2007, Neoproterozoic to Early Cambrian Small Shelly Fossil assemblages and a revised biostratigraphic correlation of the Yangtze Platform (China). Palaeogeography, Palaeoclimatology, Palaeoecology, v. 254, pp. 67-99.

Sundberg, F.A., 1994, Corynexochida and Ptychopariida (Trilobita, Arthropoda) of the Ehmaniella Biozone (Middle Cambrian), Utah and Nevada. Contributions in Science, Los Angeles County Museum of Natural History, no. 466, 137 pp.

Sundberg, F.A., 2005, The Topazan Stage, a new Laurentian stage (Lincolnian Series, "Middle" Cambrian). Journal of Paleontology, v. 79, pp. 63-71.

Sundberg, F.A., and McCollum, L.B., 1997, Oryctocephalids (Corynexochida: Trilobita) of the Lower-Middle Cambrian boundary interval from California and Nevada. Journal of Paleontology, v. 71, pp. 10651090.

Sundberg, F.A., Yuan, J.L., McCollum, L.B., and Zhao, Y.L., 2000, Correlation of the Lower-Middle Cambrian boundary of South China and Laurentia. Acta Palaeontologica Sinica, v. 38, pp.103-107.

Sundberg, F.A., Fletcher, T.P., Geyer, G., Kruse, P.D., McCollum, L.B., Pegel, T.V., Żylińska, A., and Zhuravlev, A.Yu., 2016, International correlation of the lower-middle Cambrian (Series 2-3, Stage 4-5). Memoirs of the Association of Australasian Palaeontologists, v. 49, pp. 83124 .

Sundberg, F.A., Karlstrom, K., Geyer, G., Foster, J.R., Schmitz, M., Hagadorn, W., Mohr, M., and Crossey, L., submitted, Asynchronous trilobite extinctions at the early-middle Cambrian transition. Geology.

Terfelt, F., Eriksson, M.E., Ahlberg, P., Babcock, L.E., 2008, Furongian Series (Cambrian) biostratigraphy of Scandinavia - a revision. Norwegian Journal of Geology, v. 88, pp. 73-87.

Varlamov, A.I., Rozanov, A.Yu., Demidenko, Yu.E., Karlova, G.A., Pak, K.L., Parkhaev, P.Yu., Skorlotova, N.A., Khomentovsky, V.V., and Shabanov, Yu.Ya., 2013, Proekt kembriyskoy chasti obshchey stratigraficheskoy shkaly Rossii. In: Fedonkin, M.A. (Ed.), Obshchaya stratigraficheskaya shkala Rossii: Sostoyanie i perspektivy obustroystva. Vserossiyskaya konferentsiya, Moskva, 23-25 maya 2013 g., Sbornik statey. GIN RAN, Moscow, pp. 79-87.

Wei, Sh.Ch., Fu, Y.Ch., Liang, H.P., Ge, Zh.H., Zhou, W.X., and Wang, G.Zh., 2018, Re-Os geochronology of the Cambrian stage-2 and -3 boundary in Zhijin County, Guizhou Province, China. Acta Geochimica, v. 37, pp. 323-333.

Westrop, S.R., Adrain, J.M., and Landing, E., 2011, The Cambrian (Sunwaptan, Furongian) agnostoid arthropod Lotagnostus Whitehouse, 1936, in Laurentian and Avalonian North America: systematics and biostratigraphic significance. Bulletin of Geosciences, v. 86, pp. 569 594.

Wood, R.A., Zhuravlev, A.Y., Sukhov, S.S., Zhu, M., and Zhao, F., 2017, Demise of Ediacaran dolomitic seas marks widespread biomineralization on the Siberian Platform. Geology, v. 45, pp. 27-30.

Yang, C., Li, X.H., Zhu, M., Condon, D. J., and Chin, J., 2018, Geochronological constraints on the Cambrian Chengjiang biota, South China. Journal of the Geological Society, v. 175, pp. 659-666.

Yuan, J.L., Zhao, Y.L., Wang, Z.Z., Zhou, Z., and Chen, X.Y., 1997, A preliminary study on Lower-Middle Cambrian boundary and trilobite fauna at Balang, Taijian, Guizhou, South China. Acta Palaeontologica Sinica, v. 36, pp. 494-524. (in Chinese and English)

Yuan, J.L., Zhao, Y.L., Li, Y., and Huang, Y.Z., 2002, Trilobite fauna of the Kaili Formation (uppermost Lower Cambrian-lower Middle Cambrian) from southeastern Guizhou, South China. Shanghai Science and Technology Press, Shanghai, 422 pp. (In Chinese with English summary)

Zhang, W.T., 1987, World's oldest Cambrian trilobites from eastern Yunnan. In: Nanjing Institute of Geology and Palaeontology, Academia Sinica (Ed.), Stratigraphy and Palaeontology of Systemic Boundaries in China. Precambrian-Cambrian Boundary 1. Anhui Science and Technology Publishing House, Hefei, pp. 1-16.

Zhao, Y.L., Yuan, J.L., Zhu, Chen, X.Y., and Zhou, Z., 1996, The division of the Lower-Middle Cambrian boundary in China. Journal of the Guizhou Institute of Technology, v. 25, pp. 15-20.

Zhao, Y.L., Yuan, J.L., Peng, J., Yang, X.L., and Esteve, J., 2015, Restudy of Ovatoryctocara Tchernysheva, 1962 from the Kaili Formation, Jianhe County, Guizhou, South China Annales de Paléontologie, v. 101, pp. 193-198.

Zhao, Y.L., Yuan, J.L., Babcock, L.E., Guo, Q.J., Peng J., Yin, L.M., Yang, X.L., Wang, C.J., Gaines, R.R., Esteve, J., Yang, R.D., Yang, Y.N., Sun, H.J., and Tai, T.S., 2018, Proposed Global Standard StratotypeSection and Point for the Base of the Miaolingian Series and Wuliuan Stage (Replacing provisional Cambrian Series 3 and Stage 5). Working Group on the Stage 3 GSSP, International Subcommission on Cambrian Stratigraphy, $51 \mathrm{pp}$.

Zhao, Y.L., Yuan, J.L., Babcock, L.E., Guo Q.J., Peng J., Yin, L.M., Yang, X.L., Peng, S.C., Wang, C.J., Gaines, R.R., Esteve, J., Tai, T.S., Yang R.D., Yang Y.N., Wang, Y., Sun, H.J., and Yang, Y.N., 2019, Proposed Global Standard Stratotype-Section and Point for the base of the Miaolingian Series and Wuliuan Stage (Cambrian) at Balang, Jianhe, Guizhou, China. Episodes, v. 42, pp. 165-183.

Zhu, M.Y., Babcock, L.E., and Peng, S.C. 2006, Advances in Cambrian stratigraphy and paleontology: Integrating correlation techniques, paleobiology, taphonomy and paleoenvironmental reconstruction. Palaeoworld, v. 15, pp. 217-222.

Zhu, M.Y., Zhuravlev, A.Yu., Wood, R.A., Zhao, F., and Sukhov, S.S., 2017, A deep root for the Cambrian explosion: Implications of new bio- and chemostratigraphy from the Siberian Platform. Geology, v. 45, pp. 455-458.

Zhu, M.Y., Yang, A.H., Yuan, J.L., Li, G.X., Zhang, J.M., Zhao, F.C., Ahn, S.Y., and Miao, L.Y., 2018, Cambrian integrative stratigraphy and timescale of China. Science China, Earth Sciences, v. 6. pp. 25-60.

Zhu, R.X., Li, X.H., Hou, X.G., Pan, Y.X., Wang, F., Deng, Ch.L., and He, 
H.Y., 2009, SIMS U-Pb zircon age of a tuff layer in the Meishucun section, Yunnan, southwest China: Constraint on the age of the Precambrian-Cambrian boundary. Science in China Series D, Earth Science, v. 52, pp. 1385-1392.

Zhuravlev, A.Yu., and Wood, R.A., 2018, The two phases of the Cambrian Explosion. Nature Scientific Reports (2018) 8, p. 16656, doi:10.1038/ s41598-018-34962-y.

Zhuravlev, A.Yu., Naimark, E.B., and Wood, R.A., 2015, Controls on the diversity and structure of earliest metazoan communities: early Cambrian reefs from Siberia. Earth-Science Reviews, v. 147, pp. 18-29.

Zuo, J.X., Peng, S.C., Qi, Y.P., Zhu, X.J., Bagnoli, G., and Fang, H.B., 2018, Carbon-isotope excursions recorded in the Cambrian System, South China: Implications for mass etinctions and sea-level fluctuations. Journal of Earth Science, v. 29, pp. 479-491.

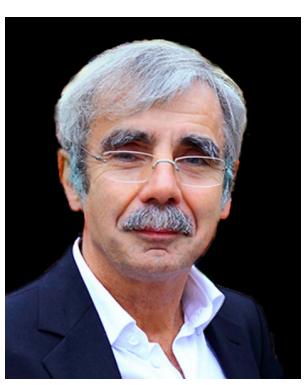

Dr. Gerd Geyer, former Secretary and ViceChairman of the International Subcommission on Cambrian Stratigraphy, holds a professorship at the Würzburg University, Germany. He is working on Cambrian paleontology and stratigraphy since 1980 and published around 120 monographs, papers and articles on Cambrian rocks and fossils. His Cambrian working area focuses on West Gondwana (Morocco, Spain, France, Germany, Israel, Jordan, Iran), but additional publications and research activities dealt with fossils from Namibia, the United States, Avalonian eastern Canada, Greenland, Siberia, Kyrgyzstan, China etc. 